\title{
Vroegdiagnostiek op late leeftijd?
}

\author{
Henk G. van der Poel
}

PSA-screening blijft de gemoederen bezighouden. Met de introductie van de mpMRI in de vroegdiagnostiek van prostaatkanker lijkt de tijd aangebroken voor een revival van de PSA-screening. Al sinds de eerste publicaties van de ERSPC was duidelijk dat PSA-screening een significante verbetering van de prostaatkankerspecifieke overleving oplevert. Toch is nationaal en internationaal altijd afstand genomen van PSA-screening om heel begrijpelijke redenen.

In de meest recente update van de ERSPC-studie in 2019 resulteerde PSA-screening in een reductie van de prostaatkankersterfte van $20 \%$ na een mediane follow-up van 16 jaar bij mannen met een leeftijd tussen de 55 en 69 jaar, maar niet bij mannen tussen de 70 en 74 jaar. Deze laatste groep mannen, die bij screening geen maligniteit hadden, werd nader onderzocht. 'Wat is hun risico op prostaatkanker?' vroegen Remmers et al. zich af in hun onderzoek dat in dit nummer van het tijdschrift wordt gepubliceerd. Opvallend was dat ondanks een negatieve PSA-screening op wat oudere leeftijd toch $7 \%$ van de mannen ouder dan 74 jaar nog met prostaatkanker werd gediagnosticeerd en dat van deze mannen een kwart aan de ziekte overleed. Selectieve vroegdiagnostiek op oudere leeftijd zou dus best lonend kunnen zijn.
De mannen in de studie van Remmers et al. hadden al een negatieve screeningsronde achter de rug. Bij nooit eerder gescreende mannen boven de 74 jaar zou het percentage met letale prostaatkanker nog wel eens hoger kunnen zijn. Bovendien zien we de laatste jaren de levensverwachting van deze mannen in $\mathrm{Ne}$ derland per jaar met een maand stijgen, wat de kans op een overlevingsvoordeel van vroegdiagnostiek voor de komende jaren alleen maar zou kunnen doen toenemen. Kortom, geen bewijs voor het nut van PSAscreening bij de oudere man, maar wel degelijk een reden om een goed geïnformeerde vitale man op leeftijd vroegdiagnostiek niet te onthouden.

Open Access This article is distributed under the terms of the Creative Commons Attribution 4.0 International License (http://creativecommons.org/licenses/by/4.0/), which permits unrestricted use, distribution, and reproduction in any medium, provided you give appropriate credit to the original author(s) and the source, provide a link to the Creative Commons license, and indicate if changes were made.

dr. Henk G. van der Poel, hoofdredacteur 